\title{
Educational Technologies: Innovation or Textbook Extension?
}

\author{
Suzanne Windsor-Liscombe \\ Independent Researcher \\ Vancouver, British Columbia
}

\begin{abstract}
This paper explores relative integration of old technology and new (digital) technologies with respect to arts-based learning. The explosion in digital technology which shifts us from 2-D to 3-D learning immediately demands that we use our eyes. Hence our learning is becoming more intensely visual. It moves us into the $21^{\text {st }}$-century virtual sphere, but is it lessening students' abilities to be creative thinkers - or do they simply need to re-think how to learn creatively? Amidst its continual evolution the sheer cost of state-of-the-art technology has created new financial challenges for school districts who strive to be accountable [1], and in step with government endeavours. Either way, how can the printed textbook, or new digital media best serve arts-integrated pedagogy? And, is one better than the other in providing interactive knowledge acquisition as against passive learning? The answer may probably lie in how they are used.
\end{abstract}

\section{Introduction}

In a short story by Isaac Asimov the future predicts an educational model whereby children learn strictly through a computer 'teacher'. Having never seen a book until somebody finds one in their grandparent's attic, the following passage nicely illustrates the difference in time and efficiency: more labour-intensive textbook as compared to the speed of new technologies. Or, the shifting virtual and erasable space of technology.

It was strange to read words that stood still - not moving on a screen. Then, when they turned back to the page before, it had the same words on it that it had had when they read it the first time... [2]

What is technology and what does it look like in education? It is certainly not a new phenomenon. The word 'technology' is in fact derived from the ancient Greek 'techne', which relates to skill, or craftsmanship, or art. [3] Therefore and depending on how one defines the word, technology has always existed, and has likely always been regarded as a means of enhancing, and inspiring student learning. Older technologies such as gestetners, opaque projectors, film reels, and slides, have all served their purpose, to take the 2-D concept of textbook learning into a $3 \mathrm{D}$ space. Yet the $21^{\text {st }}$ century has moved in double-time and now technology is no longer regarded as a curriculum enhancer but as a key means of acquiring knowledge. Where, then, does the textbook belong in this virtual learning society?

\section{Literature Review}

In the late $18^{\text {th }}$ to early $19^{\text {th }}$ centuries textbooks in North America were an economic means of providing information to a wider population. Inexpensive to re-produce they assured that a larger portion of society could be educated across vast geographic spaces [4]. In a sense, textbooks were the forerunners of computers in their ability to provide information simultaneously to large groups of students. Moreover they partnered perfectly with writing tools because if the textbook created a passive means to take in new information, then the pen created the product: writing or copying information provided by our textbooks, and memorizing it. Writing in itself is a technology, which is thought-provoking and bears careful thought; whether it is a pen or a keyboard, a textbook or digital media, the important question becomes, are we simply continuing what has gone before? Are computers another notch on an educational timeline? Are we integrating technology into our curriculum simply carrying forward the technique of teaching from a textbook? Ultimately, do we parallel technology AND curricula, or embed technology IN curricula?

A recent report from the Canadian Broadcasting Company (CBC) in August 2015 featured the work of Dr. Simon Peyton-Jones; he believes that before 
children use computer programs, they need to understand the fundamentals: "a whole new set of rules, where [in our $\mathrm{ABCs}$ ] 'C' stands for coding." [5]

Just as the foundational skills of learning to read are taught before expecting one to read a book, so Peyton-Jones states that "[if children] don't know how to program, then who is being programmed?" [6]

Typically educators ensure that there is a clear focus on underlying skills across curricula: even holding a pencil correctly is a taught skill. Yet it is easy to avoid looking below the surface of software and internet capabilities since information retrieval is so quick. Hence I question whether technology is being used at the periphery of student learning simply as a means of gathering in information, and thus by extension, a virtual textbook.

Yet as a more regularly-embedded part of our teaching, new technology provides a multitude of learning possibilities that previously were only realized through laborious undertakings requiring multiple types of technology equipment and lengthy processing times. Today, many of these same processes are possible using single multi-integrated technology devices. Larson [7] for example, explains the diversity of the e-book from the perspective of both a multi-teaching strategy and a learning tool. Within this arena proponents of new technologies have pushed for the abandonment of textbooks. One such example is found in Harding [8] who reports on Richard Culatta's (US educational technical advisor to President Obama) view that whereas "textbooks are outdated as soon as they are printed, apps and websites can be constantly updated."

\section{Seeking advantage}

While not disagreeing with Culatta's perspective, the costs of providing such technological advantage is not insignificant. Hence the neoliberal vision that has resulted in education as a marketable product for parents has become more prevalent, and raises questions about who ultimately benefits. Rae Connell in her research on neo-liberalism in education discusses the modern market-driven family's need to cope and adjust to a society that has "turned [parenting] onto new axes [sic]" [9]. Calling it the "remaking of parenthood" [10], Connell notes that neo-liberalism has caused the "disruption of family time by the 'end of welfare' and the long hours culture, as well as the increasing penetration of children's lives by unregulated marketing, commercial mass culture and entertainment media." [11] (I interpret this as meaning long work/school days followed by driving to various lessons and tutorial services, not to mention business meetings.)
Similarly Cucchiara supports this in her statement that,

A person's freedom (to choose a school, a career, or even a consumer product) carries with it a new set of responsibilities including the burden of planning for and minimizing possible negative outcomes. In this context, parenting becomes as much about managing risk as it does about nurturing children. [12]

Technology in the classroom has become a major deciding factor in parental school choice, particularly at the transition from primary to secondary school. [13] It has raised the stakes for the parent, the child, and for the school, whose responsibility to its students ultimately rests under the umbrella of annual accountability contracts submitted by school districts to higher authorities such as the B.C. Ministry of Education. [14] The regular use of new technologies in classrooms raises other issues, mainly related to costs, such as hardware and website upgrades, software, accessories, storage equipment, service contracts and site licenses. The question as to how long school districts or the public will be able to uphold the costs, is probably not answerable given the relative newness of full-scale technology in schools. Yet technology with its multi-use applications and programs is an expectation in education. Today's parents expect hands-on, interactive teaching and learning, as indicated in a recent case study.

\section{The Study}

This qualitative case study investigated parental perceptions of an arts-integrated public elementary school (Mosaic Elementary; all names of places and persons have been changed to protect confidentiality) in British Columbia, Canada. With data acquired through one-on-one interviews, it revealed that some parents were more interested in hands-on learning opportunities for their children than with academic outcomes. [15]

The impetus for the study was derived from personal observations of the school's continued increase in population over several years. Before its transition to an arts-integrated school, the population had been reduced to 90 students. After its transition in 2005 there was a steady growth in enrollments, mainly predicated on families attending from outside of Mosaic's catchment area. It eventuated in substantial changes to the overall school population as described in the following table: 
Table 1. Mosaic population over 8 years

\begin{tabular}{|c|c|c|}
\hline $\begin{array}{l}\text { School } \\
\text { Composition }\end{array}$ & $\begin{array}{l}\text { Elementary } \\
\text { Public School } \\
2005\end{array}$ & $\begin{array}{l}\text { Arts- } \\
\text { Integrated } \\
\text { Elementary } \\
\text { Public School } \\
2013\end{array}$ \\
\hline $\begin{array}{l}\text { Student } \\
\text { enrollment }\end{array}$ & 90 & 229 \\
\hline $\begin{array}{l}* \text { Enrolling } \\
\text { teachers }\end{array}$ & 4.5 & 10 \\
\hline $\begin{array}{l}\text { Non-enrolling } \\
\text { teachers }\end{array}$ & 3 & 7 \\
\hline $\begin{array}{l}\text { Ministry- } \\
\text { designated } \\
\text { students }\end{array}$ & 4 & 29 \\
\hline $\begin{array}{l}\text { English } \\
\text { language } \\
\text { learners }\end{array}$ & 16 & 15 \\
\hline $\begin{array}{l}\text { Aboriginal } \\
\text { students }\end{array}$ & 3 & 8 \\
\hline $\begin{array}{l}\text { School } \\
\text { administrator }\end{array}$ & $\begin{array}{l}1 \text { (with .4 } \\
\text { teaching } \\
\text { assignment }\end{array}$ & $\begin{array}{l}1 \text { (with } .15 \\
\text { teaching } \\
\text { assignment) }\end{array}$ \\
\hline Head Teacher & 1 & 1 \\
\hline $\begin{array}{l}\# \text { of rooms } \\
\text { utilized for } \\
\text { teaching }\end{array}$ & 10 & $\begin{array}{l}18 \text { (with the } \\
\text { addition of } 3 \\
\text { portables) }\end{array}$ \\
\hline $\begin{array}{l}\text { School } \\
\text { secretary }\end{array}$ & 1 & 1 \\
\hline $\begin{array}{l}\text { Teacher } \\
\text { assistant }\end{array}$ & 0 & .5 \\
\hline Custodian & 1.2 & 1.5 \\
\hline
\end{tabular}

Table 2. Mosaic ministry designations

\begin{tabular}{|l|l|l|}
\hline $\begin{array}{l}\text { B.C. Ministry } \\
\text { of Education } \\
\text { Designation } \\
\text { Codes }\end{array}$ & Code Descriptions & $\begin{array}{l}\text { \# of Ministry- } \\
\text { Designated } \\
\text { Students at } \\
\text { Mosaic 2013 }\end{array}$ \\
\hline D & $\begin{array}{l}\text { Chronic health } \\
\text { impairment }\end{array}$ & 3 \\
\hline G & Autism & 4 \\
\hline H & $\begin{array}{l}\text { Severe } \\
\text { behavioural/mental } \\
\text { health }\end{array}$ & 1 \\
\hline K & Mild intellectual & 1 \\
\hline P & Gifted & 8 \\
\hline Q & Learning disabled & 10 \\
\hline R & Mild behavioural & 2 \\
\hline
\end{tabular}

In addition to the dramatic rise in student enrollments, this table reveals the increase in Ministry designations - those students with special needs (ranging from gifted, learning and intellectual support, to autism, adult dependent, chronic health, blind, deaf, behavioural, and learning support). Surely these designated students also play into parental motivations for enrolling at Mosaic. The following table indicates the span of special needs students enrolled at Mosaic in 2013, for a ratio of 1:8 students.

From such data it is clear that while educators may have assumed enrolling students would have an innate interest in the arts, this was not necessarily the motivating factor. Interviews with parents reveal that other understandings and assumptions took precedence over a natural interest in the visual and performing arts.

\section{Method}

Letters of invitation for interviews were sent to school and district administrators, and those teachers who had been at Mosaic since its transition to an artsintegrated school (at least 5 years). Parents with children enrolled for at least 2 years, in an intermediate grade (4-7), and residing outside of the Mosaic catchment area were also interviewed. Additionally, invitations were extended to families who resided in the Mosaic catchment area, whose children were enrolling there for the first time. Further to this, school documents - mainly cross and out-of-district transfer forms - were scrutinized.

\section{Analysis of findings}

This qualitative research underscored the consistent parental assumption that an arts-integrated school would not use textbooks. Learning would be hands-on, thus assuring parents of a much fuller learning experience [16]. A brief sample of parent comments follows:

Not all kids are academically inclined. Not all kids learn from textbooks. (Barry, parent)

[Previous school] had lots of workbooks, we had one for math, spelling, science, every single subject had workbooks...I just thought this isn't working anymore...you know what, I think we're done here! (Parent 3)

Integrating the fine arts allows her to understand the curriculum better...in a way that is not teacher directed, not the teacher just providing the information from a textbook. (Jane, parent)

I don't know what high school will be like for her but I hope it's not just textbook based learning...some of [my older daughter's] science classes have been 
entirely textbook-based. You learn if you do the questions and you don't get close to a chemical or anything. (Meg, parent)

The assumption that textbooks and the arts do not equate, is evident across the interviews. Additionally parents believed that other traditional curricular/structural components would not be used or applied: worksheets, workbooks, and a standardized timetable. Therefore understandings of arts-integrated pedagogy are varied, the word 'arts' in itself not being fully understood. This is exemplified by Wendy a Mosaic parent, when asked what her expectations had been of the school:

I just thought of it as an arts school and to me that meant that more of the time in the classroom would mean working on non-textbook, more visual arts.

If the intent is to expose children to less passive means of learning, where then, does technology fit into the arts and how is it being used?

\section{Technology in the arts}

Within an arts-integrated school, what role does technology play? Does it sit at the periphery, its main value being its efficiency? Is it a faster way to acquire references and store assignments? Or, is it an intrinsic learning component or a curricular "add-on" [17] and by extension, a radically new type of textbook?

Interestingly, during their separate interviews, Mosaic parents never spoke to issues of digital/new media technology. Yet the B.C. Ministry of Education has been very clear about promoting multiple technologies in its $21^{\text {st }}$ Century Learning vision by advocating for students to "use educational technologies to apply knowledge to new situations, analyze information, collaborate, solve problems, and make decisions." [18] It further avers that "emerging technologies [will] provide expanded learning opportunities critical to the success of future generations." [19] Hence students will reach a higher level of achievement.

Further the "Premier's Technology Council" (2010) document includes two key points, one being technology literacy, which is explained as "the ability to use technology to amplify one's learning ability, and improve one's productivity." [20]

The other key technology point in the document is that of communications and media literacy. Here communication is interpreted as being able to relay information or concepts in person, in print, or through alternate technologies, while media literacy is comprised of both analytic skills and "the ability to use new media forms to communicate information." [21]
Most recently, the B.C. Ministry of Education has introduced a new curriculum into its public schools, grades kindergarten to 12 . Focussing on 3 core competencies: Communication, Personal and Social, and Thinking. Central to the new curriculum is a student's ability to "impart and exchange information, experiences and ideas, to explore the world around them, and to understand and effectively engage in the use of digital media. [22]

From this it is evident that the onus falls on choice schools that offer arts-integrated pedagogy to use technology to its fullest purpose and benefit for its students. Technology's centre-stage positioning in education is understandable, not least because it assures parents and the wider public that passive learning is being eclipsed by interactive learning, a word now at the forefront of education.

\subsection{Parents and technology}

Despite the Mosaic Parent Advisory Committee's financial support for state-of-the-art technology equipment, no parent interview spoke to technology as an important component of the school, or as a means to effect pedagogical change. No parent expressed a worry that their child might fall behind the speed of developing new technology as a result of being at an arts-integrated school. This is a group of parents whose main interests seem to have been in ensuring that their children had positive perceptions of themselves and of learning. Most parents discussed the fact that their children were showing confidence in doing presentations and public speaking, and therefore their children were happy, and happy about learning. They also discussed the value of creativity in learning, but it was never allied with technology - or textbooks.

It is not just the growth in creativity but also the growth and confidence that you can create something. I think she [daughter] has more confidence in her ability to create. I think it helps with academics too, because it really opens your thinking more which then translates into how you approach things, confidence, again, confidence. (Mary, parent)

Other parents discussed confidence as well, pointing to the value of drama in its potential to help "their self-confidence, their poise, they need to know how to make speeches later on," and visual art, where "they learn different ways to express themselves." (Helen, parent) Yet despite such positive statements from these interviews, and despite the negative trend toward textbooks, nevertheless Mosaic Elementary does use them in some of its subject areas. Textbooks as a resource still hold a place in education, and therefore, 
It would be as senseless to cast away a textbook once one learned how to use it as it would be to cast away a tool once one learned how to build with it. [23]

Ultimately it is how skilfully textbooks are used; although a 2D learning experience, nevertheless they can still inspire meaningful learning, and as noted earlier, are significantly less expensive, and that brings into discussion the question of equity.

\subsection{Technology equity}

It is ironic that in its mandate to move into a new $21^{\text {st }}$ century model of education technology, numerous Canadian schools are sending their textbooks to developing countries. Yet the technology inventory in any one school is likely predicated on district funding, parent interest and school demographics - socio-economics and geography. Therefore access to technology is not necessarily consistent across cities, provinces, states or countries. The underlying question becomes, how can we ensure that all elementary and secondary students have equal access to new technologies?

\section{Textbooks today}

Is it possible for technology to become a predictable routine? If technology offers interactive learning, there is still the danger of passive learning through, for example, repetitive reading, spelling or math programs, typing software, and information viewing. If technology - even such innovations as smart boards - ultimately only serve to replace film projectors or televisions, then what has been the real value in such media? Whether textbooks are now being viewed as a negative in education, nevertheless they were once a new technology. If they have outstayed their welcome, then we need to consider the same about learning technologies, some of which could become just as formulaic. And when that happens students start to use the word 'bored' - not necessarily because the curriculum is beyond them, or below them, but because learning is no longer meaningful.

Technology as a means of information storage and entertainment must still adhere to curricular criteria, and move in appropriate directions, or its situation could become likened to textbooks where they "also act as surrogate teachers when the teacher is unavailable." [24]

So too could technology be described if there is no clear intent behind its use. Of further consideration is the fact that if textbooks are only 2$\mathrm{D}$, they do ultimately require students to imagine and create based on what they can intellectually extract from the flat, written page. This is applicable across any school curriculum, not only the field of visual and performing arts.

Finally, there is another factor that seems to have been left out of the $21^{\text {st }}$ century drive to create a technology-based education. It is that of the tactile those sensory components of touch, feel, hear, smell - all of which one attains through the use of books, pencils and paper. How do our senses affect our learning, and does technology reduce a potentially important area of our being?

Interestingly, textbooks continue to hold a strong place in elementary schools-including those that offer a specific curricular focus. This fulfills Whitley's [25] prediction that "the textbook remains a vital part of student learning and will continue to be so into the $21^{\text {st }}$ century." Such reality begs the question as to whether the textbook is not so much ineffective as it is effective - depending on who uses it. And, it is confirmed by Newton \& Newton's [26] assertion that students must "learn how to use a book to good effect rather than in ways that encourage the passive acquisition of knowledge." Ultimately technology, and textbooks are a means of acquiring knowledge, but educators need to be mindful of how it is used: "a tool of instruction rather than an object of instruction" [27].

\section{Conclusion}

Historically, the textbook was a cost-effective means of mass-producing learning resources. But if the textbook provided a passive means of acquiring knowledge, the pen created the product. In his book, Orality and Literacy Walter Ong stated that "writing...initiated what print and computers only continue, the reduction of dynamic sound to quiescent space" [28]. Such a dormant space could also be inspired by new digital media, those long hours spent in front of a screen, encouraging 'word viewing' even more so than the distinctly tactile pages of a textbook.

If textbooks have been viewed negatively as the architect of sameness, with the potential to step in as substitute teachers, then one could make a similar argument for new technology; future research will ascertain the extent to which computer-generated information improves student learning, fosters creativity, or enhances critical thinking.

One other significant consideration is our students' own natural ability technology (NAT®). A student's ability to shape, size, colour, plan, space and balance pictures of words, should not be discounted. Nor should its interactive qualities be dismissed. This is a true example of techne - of technique, and hence technology: their own handson learning applied to the curriculum. It is that 
innate technique that students bring with them into the classroom.

Continued professional development, teacher collaboration and guidance from district and school administrations is vital to ensure that however we use technology in education we are indeed moving forward, because certainly technology is constantly evolving. Technology is a great enabler for educators and students. Nevertheless, it has to be meaningful, and it has to take us beyond the formulaic traditional textbook model. Otherwise as Marshal McLuhan wrote in his "The medium is the massage",

"We look to the present through a rear-view mirror. We march backward into the future" [29].

\section{References}

[1] N. Nichols and A.I. Griffith, "Talk, texts and educational action: an institutional ethnography of policy in practice," Cambridge Journal of Education, 2009, 241255, p. 242.

[2] I. Asimov, "The fun they had," in Sense and Feeling, Vancouver: Copp Clark, $1968 \mathrm{ed}$.

[3] Merriam-Webster Dictionary, 2016, http://www.mer riam-webster.com/dictionary/techne (18 June 2016).

[4] J. Wakefield, "A brief history of textbooks: where have we been all these years?" (presentation paper), p. 26, Meeting of the text and academic authors, St Petersburg, FLA, June 12-13, 1998, pp. 1-39.

[5] Canadian Broadcast Corporation (CBC), August 31, 2016.

[6] S. Peyton-Jones, Canadian Broadcast Corporation (CBC), August 31, 2016.

[7] L. Larson, "From print books to e-books: the changing nature of literacy," Kappa Delta Pi Record, 2013, 49(4), 168-173, p. 170.

[8] E. Harding, "Bin textbooks by 2020 and go digital, schools urged: Education expert says apps and websites that can be constantly updated will make them obsolete," http://www.dailymail.co.uk/news/article-3155599/Bintextbooks-2020-digital Html\#ixzz3hP1WFJ12. (5 July 2015).

[9] R. Connell, "The neo-liberal parent and schools," in G. Martell (ed.), Breaking the iron cage: resistance to the schooling of global capitalism, Ottawa: Canadian centre for policy alternatives, 2008, pp. 177-193.

[10] R. Connell, "The neo-liberal parent and schools," in G. Martell (ed.), Breaking the iron cage: resistance to the schooling of global capitalism, Ottawa: Canadian centre for policy alternatives, 2008, pp. 177-193.
[11] R. Connell, "The neo-liberal parent and schools," in G. Martell (ed.), Breaking the iron cage: resistance to the schooling of global capitalism, Ottawa: Canadian centre for policy alternatives, 2008, pp. 177-193.

[12] M. Cucchiara, "Contracts choice and customer service: marketization and public engagement in education," Teachers College Records, 2013, 113(11), pp. 2460-2502.

[13] D. Reay, and S. Ball, S. (1998). "Making their minds up": family dynamics of school choice. British Educational Research Journal, 1998, 24(4), pp. 431-448.

[14] N. Nichols, and A.I. Griffith, "Talk, texts and educational action: an institutional ethnography of policy in practice," Cambridge Journal of Education, 2009, 39(2), pp. 241-255.

[15] S. Windsor-Liscombe, "Parental perceptions of an arts-integrated focus school: case study of a public fine arts elementary school in British Columbia" (doctoral dissertation); cIRcle, http://circle.ubc.ca (18 December 2014).

[16] S. Windsor-Liscombe, "Parental perceptions of an arts-integrated focus school: case study of a public fine arts elementary school in British Columbia" (doctoral dissertation); cIRcle, http://circle.ubc.ca (18 December 2014).

[17] L. Bresler, "The subservient, coequal affective and social integration styles and their implications for the arts," Arts Education Policy Review, 1995, para 18, 96(5), pp. 31-37.

[18] Premiers' technology council: A vision for 21st century education, B.C. Ministry of Education, 2010, http://www.bced.gov.bc.ca/dist_learning/21 century_learnin g.htm (1 October 2013)

[19] Premiers' technology council: A vision for 21st century education, B.C. Ministry of Education, 2010, http://www.bced.gov.bc.ca/dist_learning/21century_learnin g.htm (1 October 2013).

[20] Premiers' technology council: A vision for 21st century education, B.C. Ministry of Education, 2010, http://www.bced.gov.bc.ca/dist_learning/21century_learnin g.htm, 2010 (1 October 2013).

[21] Premiers' technology council: A vision for 21st century education, B.C. Ministry of Education, 2010, http://www.bced.gov.bc.ca/dist_learning/21century_learnin g.htm, 2010 (1 October 2013).

[22] Building student success. B.C's new curriculum, B.C. Ministry of Education, 2015, http://curriculum.gov.bc.ca (15 August 2015).

[23] J. Wakefield, "A brief history of textbooks: where have we been all these years?" (presentation paper), p. 4, Meeting of the text and academic authors, St Petersburg, FLA, 1998, June 12-13, pp 1-39. 
[24] G. Harrison, "How do teachers and textbook writers model scientific ideas for students?" Research in Science Education, 2001, 31: 401-435, p. 419.

[25] Whitley, in J. Wakefield, "A brief history of textbooks: where have we been all these years?" (presentation paper), p. 4, Meeting of the text and academic authors, St Petersburg, FLA, June 12-13, 1998, pp. 1-39.

[26] L.D. Newton, and D.P. Newton, "Thinking about art: could elementary textbooks serve as models of practice to help new teachers and non-specialists support reasoning in art?" International Journal of Art and Design Education, 2005, 24(3), p. 322.

[27] J. Wakefield, "A brief history of textbooks: where have we been all these years?" (presentation paper), p. 4, Meeting of the text and academic authors, St Petersburg, FLA, June 12-13, 1998, pp. 1-39.

[28] W. Ong, Orality and Literacy. London: Methuen \& Co. Ltd., London, 1982.

[29] M. McLuhan and Q. Fiore, The medium is the massage: an inventory or effects, Bantam, New York, 1967. 